\title{
Exposure, Perception and Advantages about Weather based Agro-advisory Services by Selected Farmers of Anand District, India
}

\author{
K. Manjusha ${ }^{1 *}$, P. Nitin ${ }^{1}$, D. Suvarna ${ }^{1}$ and H. M. Vinaykumar ${ }^{2}$ \\ ${ }^{1}$ Department of Agricultural Meteorology, ${ }^{2}$ Department of Extension Education and \\ Communication, B. A. College of Agriculture, Anand Agricultural University, Anand 388110 \\ *Corresponding author
}

\section{A B S T R A C T}

\begin{tabular}{|l|}
\hline Ke y w or d s \\
Adaptation, \\
Agromet, Crop, \\
$\begin{array}{l}\text { Forecasting, } \\
\text { Perception, Weather }\end{array}$ \\
\hline Article Info \\
\hline $\begin{array}{l}\text { Accepted: } \\
\text { 17 April } 2019 \\
\text { Available Online: } \\
\text { 10 May } 2019\end{array}$ \\
\hline
\end{tabular}

\section{Introduction}

In India weather services for the farmers was started by India Meteorological Department (IMD) in the 1945. At present these advisory bulletins or weather services are divided into three levels such as National Agromet Advisory Bulletin, State Agromet Advisory Bulletin and District Agromet Advisory Bulletin. National Agromet Advisory bulletin are basically for national level agricultural
A study was conducted during year 2018-19 to know the productiveness and functionality of Agro-met Advisories Services (AAS) and measured by the social economics benefit by adopting it at Anand district which falls under the semi-arid zone of Gujarat state. For this analysis, two groups of farmers were selected namely, farmers who adopted the Agro-met Advisories Services regularly for their field operation and the other group of farmers who were unaware of Agro-met Advisories Services (Non-AAS farmers). The data were collected by using questionnaires' from 110 farmers among that 70 are associated with Agro-met Advisories Services (AAS) and 40 farmers who were not associated with AAS. The farmers who adopted the Agro met Advisories services in their day to day agricultural activities have earned extra benefits like $80.91 \%, 77.27 \%, 79.09 \%, 79.09 \%$ and $66.36 \%$ in crop growth, plant protection, irrigation, income and adverse weather issues related to animal husbandry, respectively. Thus, the application of Agro-met Advisory Bulletin based on current technology weather forecast is a beneficial mode for doubling the production of crop and income of farmers. This study will help the planners, executors, researcher's and administrators to know that in which segment of the agriculture farmer's research and policy can be formulated in future. planning \& management. The prime user are Crop Weather Watch Group (CWWG), Ministry of agriculture and farmer welfare. It was started by National Agromet Advisory Services centre, Agricultural Meteorology Division, India Meteorological Department. It is very useful for all ministries (state\& central), NGO, Organization for their use. State Agromet Advisory bulletin are basically for State level agricultural planning \& management. The prime users are ACWWG 
(Agricultural Crop Weather Watch Group). It was started by 22 AAS units at different state capitals.it is very useful for fertilizer industry, Pesticide industry, Irrigation Department, Seed Corporation, Transport and other organizations which provide inputs in agriculture for their use. District Agromet Advisory bulletin is basically for the farmers of the districts. The prime user is ACWWG (Agricultural Crop Weather Watch Group). It was started by 30 AMFUs functioning at State Agricultural Universities.it contain advisory for farmers related to weather sensitive agricultural practices from sowing to harvest.it also useful for horticultural crops and livestock management.

\section{Agro-Meteorological Field System (AMFUS) and Agro-advisory}

The National Centre for Medium Range Weather Forecasting (NCMRWF), Ministry of Earth Sciences (MoES), Government of India in collaboration with India Meteorological Department (IMD), Indian Council of Agricultural Research (ICAR) and State Agricultural Universities (SAU's) had been providing Agro-meteorological Advisory Services (AAS) at the scale of agroclimatic zone to the farming community based on location-specific medium-range weather forecast. The core aim of AAS introduced by IMD is to set up demonstrations for multidisciplinary and multi-institutional services to the farming community. AMFUS prepares district wise agro-advisories depending on the above forecast and crop information. There are 130 AMFUS (Harsh, 2018) were established by Ministry of Earth Sciences which cover agro all agro-climatic zones on mean each covers 4 to 6 districts as shown in Figure 1. These services are provided by State Agriculture Universities (SAU's), Indian Council of Agricultural Research (ICAR), Indian Institute of Technology (IIT) by providing grant in aid from IMDnodal officer and technical officer who make advisory bulletins in consultation with the panel of experts, already created at their unit. Agro-met bulletin includes particular advice on field crops, horticultural crops, and livestock, etc. on which farmers need to act upon. Twice a week i.e., Tuesday and Friday. So that farmers can use natural resources in an effectual manner both in quantity and quality (Ray et al., 2017). Due to AAS, the farmers are capitalizing the situation of weather condition in order to utilize the resource and minimize the loss due to bad/abnormal weather condition (Venkataraman,2004). The statistical methods and mathematical methods are used to increase the trustworthiness of the weather prediction (Damrath et al., 2000). However, people-centric group's dynamic methodology is still lacking (Sharma et al., 2008). The district level agro-met advisory bulletins are prepared and spread information for the help of the farmers of respective district. The impact analysis (Rathore and Parvinder, 2008) has showed that the weatherbased agro-meteorological service is able to reduce the cost of cultivation by two to five per cent.

IMD, Ministry of Earth Sciences (MoES) under the scheme "GraminKrishiMausanSeva (GKMS)" issues district level weather forecast covering all the districts in the country. So in Gujarat Anand district is selected under GKMS, Anand Agricultural University, Anandis actively busy in making weather-based agromet-advisories for the farming community of the zone. Supported weather related forecast received from IMD, advisories are prepared for all the districts of the zone and dispelled through numerous mass media like newspaper, TV channels, and web etc. roughly 1, 02,133and registered farmers of middle Gujarat receiving SMS through m-kisanportal biweekly (Tuesday and Friday). The analysis output, rising out of 
analysis works counselled for the scientific and farming communities are utilized in preparing the Agro-Advisory in consultation with specialists of various disciplines viz. Agronomy, Entomology and Plant Pathology etc. Department additionally provides coaching to subject material specialists of state officials through TV and air programme. Weather and climate awareness programme is additionally organized for the students/public/farmers from time to time. Department acts as a lead centre in Gujarat in providing technical ability for institution, maintenance of agrometeorological instruments, assortment of knowledge and their process. Department has updated its agrometeorological observatories in the slightest degree the sixteen analysis stations spread over the jurisdiction of AAU.

The existing perception levels of the farmers towards weather forecasting indicate that there was considerable profit to farmers who have adopted the Agromet Advisories Services made from GKMS Unit of Anand district. It has conjointly helped not only in encouraging the acquisition and use of recent agricultural production technologies and practices, but in nurturing weather-based irrigation management, pest/ disease management, along with greater use of postharvest technologies and industrial promoting of commodities

\section{Objectives}

Weather forecast and weather primarily based agromet advisories facilitate in increasing the economic profit to the farmers by suggesting them the acceptable management practices consistent with the weather. This study was conducted to review the effectiveness, extent of relevance and adaptation of the Agromet Advisory Services (AAS) in enhancing the economic come and net profit.

\section{Materials and Methods}

\section{Area of study}

Anand districts located in Gujarat state in western India is popularly known as milk capital of India. Located at $226^{\prime}$ 'to $22{ }^{\circ} 43^{\prime} \mathrm{N}$ latitude and $72 \cdot 2$ ' to $73.12^{\prime}$ 'E longitude with altitude $43 \mathrm{~m}$ above Mean Sea Level (MSL).This district is situated in middle part of Gujarat near the Gulf of Cambay. Anand is district is head quarts for 8 talukas. The district has a total area of 2951 sq. $\mathrm{km}$ and the total population is 20, 92,745 as per 2011 Census. The rainfall in Anand district is ranged between 286.9 to $1693.4 \mathrm{~mm}$. Anand is having a semi-arid and sub-tropical climate with fairly dry and hot summers. May is the hottest month with mean maximum temperature around $40^{\circ} \mathrm{C}$. Southwest Monsoon is very precious for agricultural sector. Medium range forecast is provided to zonal farmer by agro-meteorological observatory located at Department of Agriculture Meteorology, B.A.College of Agriculture, Anand Agricultural University (AAU), Anand.

\section{Selection of villages and respondents}

The total sample for the study was 110 farmers of nearby villages of Anand district headquarter like, Gada, Balinta and Dali the categories of farmers includes marginal, small and medium. Among that 70 were associated with AAS(Agro-met Advisory Services) and 40 were not associated with AAS.

\section{Data collection method}

A structured questionnaire was developed to collect data on farmer's perception about climate change and adaptation to climate change and their characteristics. The schedule was first developed in Gujarati (vernacular language) to help the respondents to 
understand the questionnaires and give appropriate responses clearly. The data collected from the respondents were tabulated and analysed using the statistical tools and techniques. The data were presented in frequency and percentage to understand the level of farmer's perception about climate change and their adaptation measures to climate change. A frequency distribution was used to quantify the different personal, social, psychological and economical characteristics of the farmers. It was also used in the response for analysis of knowledge and adoption statements. The percentage was used to make the simple comparison of different groups wherever needed.

\section{Results and Discussion}

Distribution of farmer's categories based on age, education level and land holdings

The adaptation measures initiated by farmers revealed that 50.91 per cent of the farmers belonged to the old age group and followed by middle (33.64 per cent) and young age (15.45 per cent)group (Fig. 2). It was found that age had a remarkable relationship with adaptation measures taken up by farmers who are associated with AAS to mitigate the vagaries effects of climate change. This means that differences in the age level of respondents had directly influenced the adaptation. The study implies that with an increase in the age, farmers would like to take up more adaptation measures, which are middle-aged, are keen to know and try various technologies as adaptation measures. Similarly, 44.55per cent of the respondents had higher secondary level of education, followed by primary, college $\&$ above and secondary level education with 20 per cent, 11.82 per cent and 10.91 per cent respectively. The 12.73 per cent respondents were illiterate. Education level of farmers was found to be positive with their adaptation measures due to climate change given by
AAS. It implies that with an increase in the education level of farmers there would be increase in the adaptation measures. Education influenced the farmers to know the recent technologies which are suitable in the changed conditions of climate for their farm and consequently helped them to acquire suitable methods and technologies.39.09 per cent of the farmers had less than 1 hector land followed by 32.73 percent Medium (2.01 to $4.0 \mathrm{ha})$ and then after 16.36 per cent Small (1.01 to $2.0 \mathrm{ha}$ ) and 11.81 per cent Large (Above 4.0 ha) landholding. Land holdings are maximized if they get profit and which in turn result getting more profit making perception favorable. The 60.91 per cent farmer possesses the livestock viz., cow, buffalo, goat, etc. The study reveals that there was good relationship between land holding and adaptation measures of farmers to mitigate adverse effects of climate change. Higher the land holding status farmer are more concern in their farming and tries to acquire the technologies and farming practices to overcome the ill effects of climate change in order to reduce the vulnerability and to get benefit in their livelihood (Fig. 2) adverse weather effect on livestock production were incidence of diseases and external parasites in animal, loss of forages and fodders, heat stress, water scarcity, infertility, decline in the milk yield and lactation period. It was found that awareness campaign on climate change was significantly positive among livestock holders for climate change information

\section{Adaptation measures initiated by farmers based on Social participation and Extension contact}

In Table 1 , it can be said that 46.36 per cent of the farmers were member in more than one organization, followed by 36.36 per cent had a membership in one organization, 7.27 per cent had a positional holder in various organization and 10 per cent had a no 
membership respectively. The study implies that having more interaction with socialorganization have developed knowledge and made good perception about Agro-met advisory Services. Farmers are regularly visiting scientist of the state agricultural universities, gram sevak, progressive farmers, scientist of KVK, Agro Service Centres, officers of Department of Horticulture, Agriculture Officer and Officers of NGO ATMA are 50.90, 49.09, 43.63, 39.09, 34.54, $30.00,29.09$ and 28.18 percent respectively (Table 2). Farmers who are daily in touch with social organization had developed good livelihood, education and income along with their existing farming experience gained through increased extension contact helped them to know the appropriate farming activities and technologies to rectify the adverse effects of climate change.

\section{Adaptation measures initiated by farmers based on Mass media}

It is revealed that mainly farmers use daily newspapers and Agricultural Television Programme in percentage of 57.27 and 54.54 percent, respectively and twenty percent of farmers reported that user of the internet for farming purpose. While, 50 per cent of respondents were reading an agricultural magazine and 24.54 per cent respondents showed their interest in use of radio for agricultural-based practices (Table 3 ).

Mass media is playing significant role as a tool in the dissemination of information more precisely. Hence, Study implies that mass media tool was found to have positive and significant relationship with the adaption strategies. Mass media helps to upgrade the agricultural activities and allied sector including daily weather conditions according to modern technologies which are good among in farmer.

\section{Distribution of farmer's categories based on crop management and animal husbandry}

The adaptation measures initiated by farmers for crop disease forecasting from the present studies was found that nearly 70.00 percent farmers believe that weather affect the crop health or growth. Total 73.64 percent farmer use weather based advisory for managing their crop disease while, 67.27 percentage weather based Agro-met Advisory Services to control crop insect pest. Approximately, 72.73 percentage weather-based Agro-met Advisory Services for scheduling irrigation in field (Table 4). Accurately and timely forecast is necessary for proper crop management. The crop yield forecasting models are developed at different stages of the crops combining statistical, crop growth simulation and other methods which take under consideration the influence of weather and technological advances on crop yield. Study implies that crop-related an issue forecast was found to have significant relationship with the adaptation of farmers. These AAS helps farmers to know the latest technologies which are a good sign that speaks about the interest of the farmers.

\section{Distribution of farmers based on the AAS}

To explore the Socio-economic advantages obtained by the farmers who have acquired the Agro-met Advisories (AAS farmers) and those who have not acquired the advisories as any information provided to them. The data given in Table 5 revealed that 63.64 percent of the respondents (AAS) receive and uses weather based agro advisory on every Tuesday and Friday through T.V. and Newspaper and SMS in mobile. They were benefited 79.09 percent by saving expenditure on irrigation. They improved crop production by 80.91 percent and also benefited in animal husbandry by 66.36 percent. While 
20.91,33.64 \&19.09 were looser in annual income, animal husbandry and crop production that is percent as shown in table 5 . The study says that farmers who are associated with AAS had positive perception and who are not associated with AAS had a negative perception. Also who are adopting AAS is highly benefited in crop production, crop yield, irrigation and income.

\section{Suggestions of farmers in the feedback} form

Climate change has wide-ranging effects on the environment, agriculture, food security, animal health and biodiversity in recent past. Changes in rainfall pattern are likely to lead to severe water shortages and/or flooding.
Rising temperatures will cause shifts in crop growing seasons which affects food security and changes in the distribution of pest and disease in field and horticultural crops and also spread of new disease in animal husbandry.

The study revealed that farmer of all categories has lot of questions in their mind about the better way to crop management and to secure maximum income, improve nutrition of their families and to protect their crop from adverse weather conditions (Table $6)$.

Table.1 Distribution of the respondents according to their Social Participation

$(\mathrm{n}=110)$

\begin{tabular}{|c|l|c|c|}
\hline Sr. no. & \multicolumn{1}{|c|}{ Social Participation } & \multicolumn{2}{|c|}{$\begin{array}{c}\text { Beneficiary of Weather Based Agro } \\
\text { Advisory services }\end{array}$} \\
\cline { 3 - 4 } & Frequency & Per cent(\%) \\
\hline 1 & No membership & 11 & 10.00 \\
\hline 2 & $\begin{array}{l}\text { Membership in one } \\
\text { organization }\end{array}$ & 40 & 36.36 \\
\hline 3 & $\begin{array}{l}\text { Membership in more than one } \\
\text { organization }\end{array}$ & $\mathbf{5 1}$ & $\mathbf{4 3 . 3 6}$ \\
\hline 4 & Position holder in organization & 8 & 7.27 \\
\hline
\end{tabular}

Table.2 Distribution of the respondents according to their extension contact $(n=110)$

\begin{tabular}{|c|l|c|c|}
\hline & & \multicolumn{2}{|c|}{$\begin{array}{c}\text { Beneficiary of Weather Based Agro } \\
\text { Advisory services }\end{array}$} \\
\hline Sr. No. & \multicolumn{1}{|c|}{ Extension Contact } & Frequency & Percent(\%) \\
\hline $\mathbf{1}$ & Gram Sevak & 54 & 49.09 \\
\hline $\mathbf{2}$ & Agricultural University Scientist & 56 & 50.90 \\
\hline $\mathbf{3}$ & KVK Scientist & 43 & 39.09 \\
\hline $\mathbf{4}$ & Department of Horticulture & 33 & 30 \\
\hline $\mathbf{5}$ & Progressive Farmers & 48 & 43.63 \\
\hline $\mathbf{6}$ & NGO/ATMA Officer & 31 & 28.18 \\
\hline $\mathbf{7}$ & Agro Service Centers & 38 & 34.54 \\
\hline $\mathbf{8}$ & Agriculture Officer & 32 & 29.09 \\
\hline
\end{tabular}


Table.3 Distribution of the respondents according to their Mass media exposure

$(n=110)$

\begin{tabular}{|c|l|c|c|}
\hline $\begin{array}{c}\text { Sr. } \\
\text { No. }\end{array}$ & \multicolumn{1}{|c|}{ Mass Media } & \multicolumn{2}{|c|}{$\begin{array}{c}\text { Beneficiary of Weather Based Agro } \\
\text { Advisory services }\end{array}$} \\
\cline { 2 - 4 } & & Frequency & Percent $(\%)$ \\
\hline $\mathbf{1}$ & Radio & 27 & 24.54 \\
\hline $\mathbf{2}$ & $\begin{array}{l}\text { Agricultural television } \\
\text { programme }\end{array}$ & 60 & 54.54 \\
\hline $\mathbf{3}$ & $\begin{array}{l}\text { Farm related information in } \\
\text { daily newspapers }\end{array}$ & 63 & 57.2 \\
\hline $\mathbf{4}$ & Farming Mobile Applications & 30 & 27.27 \\
\hline $\mathbf{5}$ & Internet use for farming & 22 & 20.00 \\
\hline $\mathbf{6}$ & Agricultural magazine & 55 & 50.00 \\
\hline
\end{tabular}

Table.4 Details for the usefulness of the advisory given by farmers

$(n=110)$

\begin{tabular}{|c|c|c|c|}
\hline \multirow[t]{2}{*}{$\begin{array}{l}\text { Sr. } \\
\text { No. }\end{array}$} & \multirow[t]{2}{*}{ Statements } & \multicolumn{2}{|c|}{$\begin{array}{c}\text { Beneficiary of Weather Based Agro } \\
\text { Advisory services }\end{array}$} \\
\hline & & Frequency & Percent(\%) \\
\hline 1 & $\begin{array}{l}\text { There has been an increase in the } \\
\text { production of crop due to availability of } \\
\text { weather-based agro advisory. }\end{array}$ & 77 & 70.00 \\
\hline 2 & $\begin{array}{l}\text { It Income is increased through Weather } \\
\text { Based agro advisory. }\end{array}$ & 81 & 73.64 \\
\hline 3 & $\begin{array}{l}\text { We get the benefit from abnormal weather } \\
\text { forecast related to irrigation or plant } \\
\text { protection. }\end{array}$ & 74 & 67.27 \\
\hline 4 & $\begin{array}{l}\text { We get the benefit from abnormal weather } \\
\text { forecast related to animal husbandry. }\end{array}$ & 80 & 72.73 \\
\hline 5 & $\begin{array}{l}\text { The weather forecasts and agro advisory, } \\
\text { irrigation related costs are reduced. }\end{array}$ & 61 & 55.45 \\
\hline 6 & $\begin{array}{l}\text { We get benefit in crop production by using } \\
\text { information of spraying of } \\
\text { insecticides/pesticides/fungicides from } \\
\text { weather based agro advisory. }\end{array}$ & 35 & 31.82 \\
\hline 7 & $\begin{array}{l}\text { We get the benefit from abnormal weather } \\
\text { forecast related to animal husbandry. }\end{array}$ & 64 & 58.18 \\
\hline 8 & $\begin{array}{l}\text { The weather forecasts and agro advisory, } \\
\text { irrigation related costs are reduced. }\end{array}$ & 69 & 62.73 \\
\hline 9 & $\begin{array}{l}\text { We get benefit in crop production by using } \\
\text { information of spraying rof of } \\
\text { insecticides/pesticides/fungicides from } \\
\text { weather based agro advisory. }\end{array}$ & 85 & 77.27 \\
\hline
\end{tabular}


Table.5 Scoring pattern of advisory Services of the farmers

$(\mathrm{n}=110)$

\begin{tabular}{|c|l|c|c|c|c|}
\hline Sr. No & \multicolumn{1}{|c|}{ Particulars } & \multicolumn{2}{|c|}{$\begin{array}{c}\text { Beneficiary of } \\
\text { Weather Based Agro } \\
\text { Advisory services }\end{array}$} & $\begin{array}{c}\text { Non- Beneficiary of } \\
\text { Weather Based Agro } \\
\text { Advisory services }\end{array}$ \\
\cline { 3 - 6 } & & Frequency & $\begin{array}{c}\text { Percent } \\
\text { (\%) }\end{array}$ & Frequency & $\begin{array}{c}\text { Percent } \\
(\mathbf{\%})\end{array}$ \\
\cline { 3 - 6 } & & $\mathbf{7 0}$ & $\mathbf{6 3 . 6 4}$ & $\mathbf{4 0}$ & $\mathbf{3 6 . 3 6}$ \\
\hline 2 & $\begin{array}{l}\text { There has been an increase in the } \\
\text { production of crop due to availability } \\
\text { of weather-based agro advisory. }\end{array}$ & 57 & 80.91 & 13 & 19.09 \\
\hline 3 & $\begin{array}{l}\text { It Income is increased through } \\
\text { Weather Based agro advisory. }\end{array}$ & 56 & 79.09 & 14 & 20.91 \\
\hline 3 & $\begin{array}{l}\text { We get the benefit from abnormal } \\
\text { weather forecast related to irrigation } \\
\text { or plant protection. }\end{array}$ & 54 & 77.27 & 16 & 22.73 \\
\hline 4 & $\begin{array}{l}\text { We get the benefit from abnormal } \\
\text { weather forecast related to animal } \\
\text { husbandry. }\end{array}$ & 47 & 66.36 & 23 & 4 \\
\hline 5 & $\begin{array}{l}\text { The weather forecasts and agro } \\
\text { advisory, irrigation related costs are } \\
\text { reduced. }\end{array}$ & 56 & 79.09 & 16 & 5 \\
\hline 6 & $\begin{array}{l}\text { We get benefit in crop production by } \\
\text { using information of spraying of } \\
\text { insecticides/pesticides/fungicides } \\
\text { from weather based agro advisory. }\end{array}$ & 57 & 80.91 & 13 & 6 \\
\hline
\end{tabular}

Table.6 Suggestions given by Farmers

\begin{tabular}{|c|c|c|c|}
\hline \multirow{3}{*}{$\begin{array}{l}\text { Sr. } \\
\text { No. }\end{array}$} & \multirow{3}{*}{ Statements } & \multirow{2}{*}{\multicolumn{2}{|c|}{$\begin{array}{c}\text { Beneficiary of Weather } \\
\text { Based Agro Advisory } \\
\text { services }\end{array}$}} \\
\hline & & & \\
\hline & & Frequency & Per $\operatorname{cent}(\%)$ \\
\hline 1 & $\begin{array}{l}\text { Should the language of the weather forecast message be } \\
\text { Gujarati }\end{array}$ & 99 & 90.00 \\
\hline 2 & $\begin{array}{l}\text { The information given to you Should be in the S.M.S } \\
\text { form }\end{array}$ & 82 & 74.55 \\
\hline 3 & $\begin{array}{l}\text { Should a weather forecast message be given twice in a } \\
\text { week }\end{array}$ & 68 & 61.82 \\
\hline 4 & $\begin{array}{l}\text { Want to get forecasts three days ahead of the forecast of } \\
\text { hazardous weather condition }\end{array}$ & 92 & 83.64 \\
\hline 5 & $\begin{array}{l}\text { According to your opinion, does rainfall affect } \\
\text { agriculture and income }\end{array}$ & 90 & 81.82 \\
\hline
\end{tabular}


Fig.1 Flow chart of agromet advisory

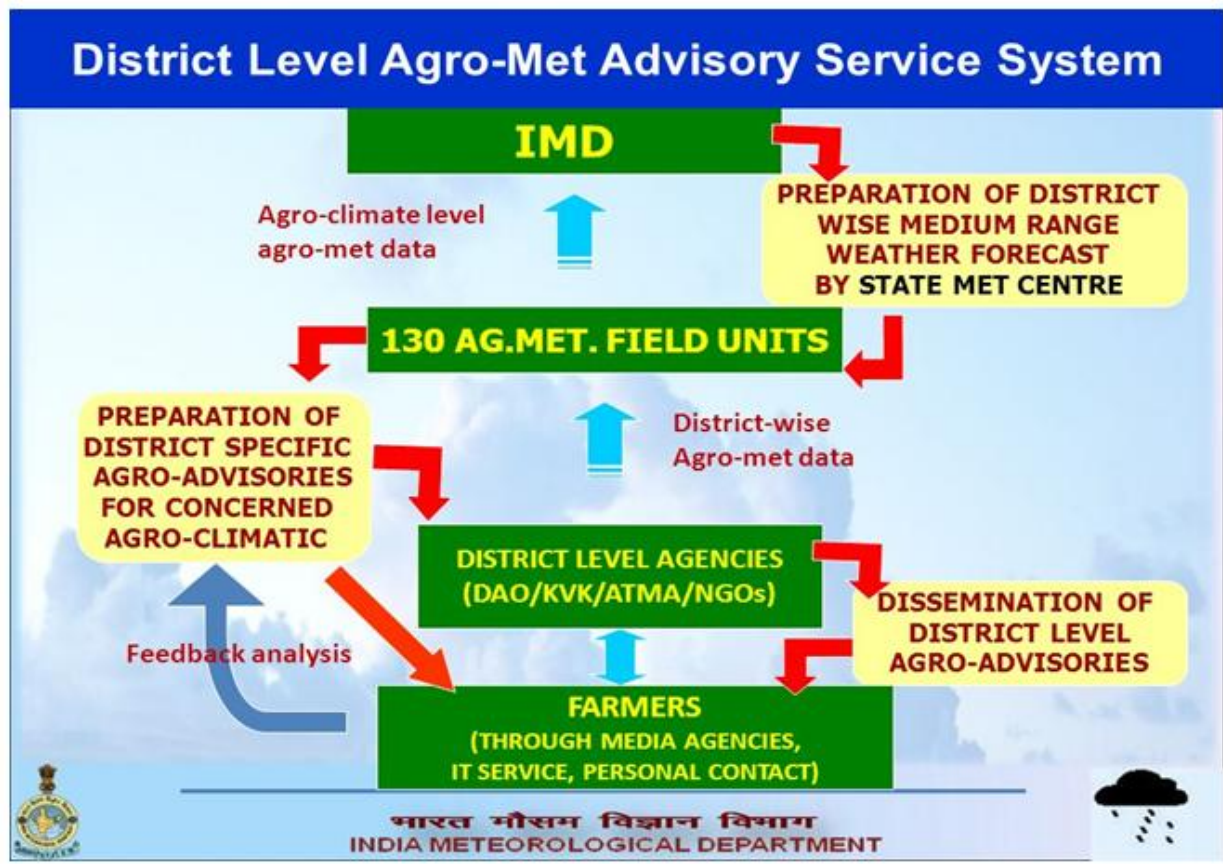

Source : Online

Fig.2 Distribution of the respondents according to their age, education, land hold and live stock

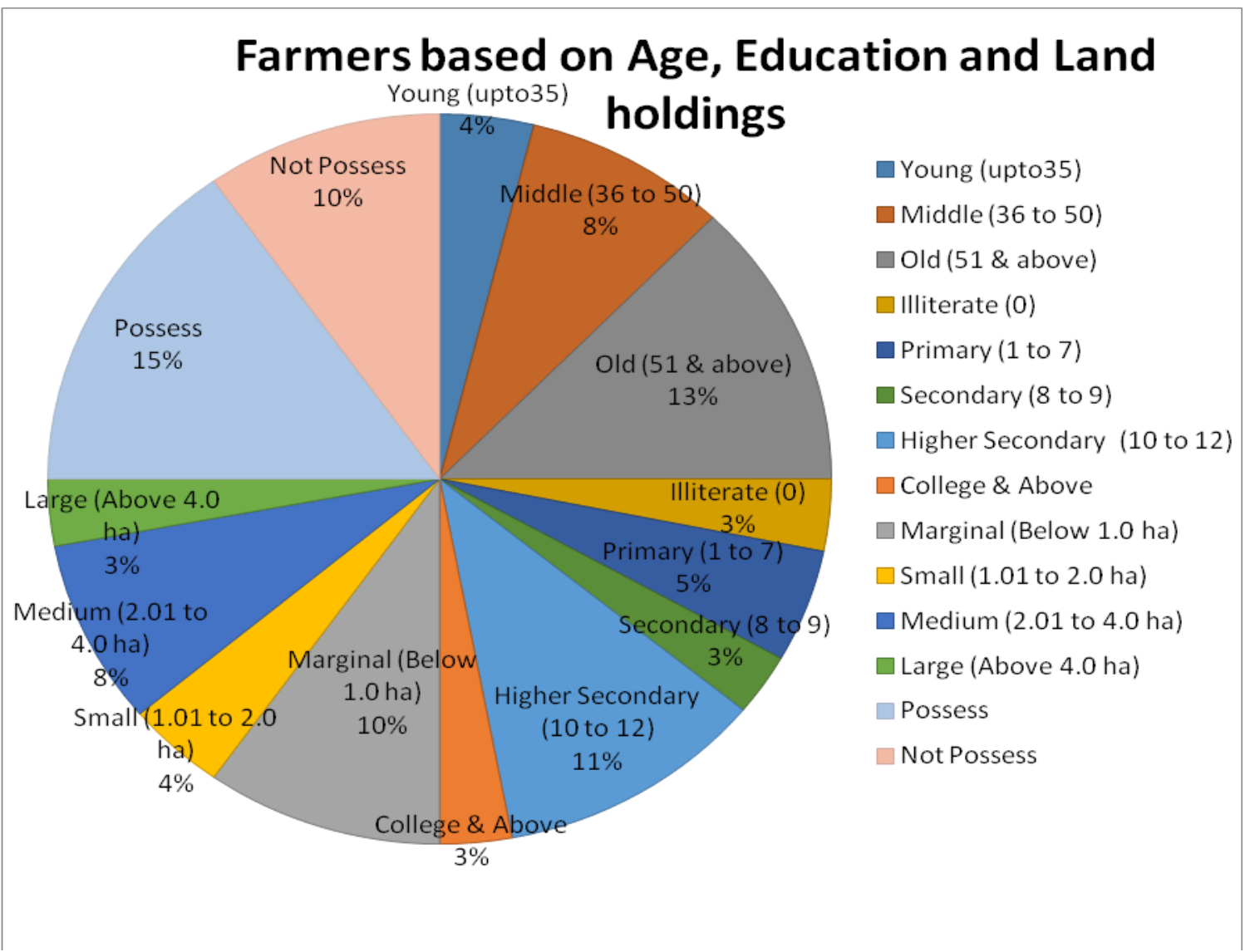


A major barrier like higher cost of agricultural inputs, non-availability of timely inputs, low price for their produce and higher wage rate, etc., were experienced by the farmers to start adaptation measures to mitigate ill effects of climate change. The data revealed that the majority of the farmer suggested early warning should be given to the farmers about environmental changes, creating awareness to the farmers about appropriate adaptation measures against climate change and development.

Adapting to climate change will entail adjustments and changes at every level starting from farming community, institute to national and international. State agricultural universities and IMD identified as having the responsibility to scale up lessons learned and products from adaptation projects for use nationally. In order to do so, creating awareness on adaptation of Agro-met Advisories among the farmers for agricultural practices and planners/political decision makers beyond the environment sectors, and training of farmers and block level extension officers within these areas, is a useful start. Operational guidelines could be prepared to help integrate adaptation into various farm and allied sectors.

In conclusion, mostly respondents were of old age group that is more than 51 years and higher secondary educated with majority of land holding were marginal with 60.91 percent animals possesses. It was concluded that weather-based Agromet Advisory is useful to the farmers and plays a crucial role to improve their agricultural income and protecting their crop in different seasons. If there is chance of any disaster occurrence they want suggestion having special advisory that to three days in advance and should be made available to farmers in the form of SMS in Gujarati language. AAS farmers got higher advantages than non-AAS farmers. This study will help the planners, executors, researcher's and administrators to know that in which segment of the agriculture farmer's research and policy can be formulated in the coming climate changing era.

\section{Acknowledgement}

The authors are highly acknowledged the IMD, New Delhi for providing finance to the project namely Gramin Krishi Mausam Seva (GKMS) and Dr.N.B.Chauhan, Professor and Head, Dr.J.B.Patel, Associate Professor, Department of Extension and Communication for giving valuable guidance and preparation of the manuscript. Also, Acknowledge Mehul Vasani, JRF, Department of Agricultural Meteorology, helped in analysis work.

\section{References}

Damrath, U., Doms, G., Friihwald, D., Heise, E., Richter, B. and Steppeler, J. 2000. Operational quantitative precipitation forecasting at the German Weather Service. Journal of Hydrology. 239: 260-85.

Harsh, V. 2018. Met department issues district level weather forecasting covering all districts of the country http://pib.nic.in/newsite/PrintRelease.as px?relid=180667.18-july-2018

Krishna, P., R. 2014 Development of e agromet prototype to improve the performance of integrated agromet advisory service. Databases in networked information systems (DNIS2014). Report No: IIIT/TR/2014/1, March.

Rathore, L.S. and Parvinder Maini, 2008: Economic impact assessment of agrometeorological advisory service of NCMRWF, Report No. NMRF/PR/01/2008, 104pp, Published by NCMRWF, Ministry of Earth Sciences, Government of India 
Ray, M., Patro, H., Biswasi, S., Dash, S.,R. and Dash, A., C. 2017 Economic assessment of weather based agromet advisories In Keonjha rdistrict, Odisha, Vayu Mandal 43(1):

Sharma, S. K., Kothari, A. K., Sharma, R.K. and Jain, P.M. 2008. Capitalizing on agro-advisory services for higher productivity in rainfed agroecosystem A case study. Journal of Agrometeorology (Special issue- Part 1): 219-224.

Venkataraman, 2004. Climatic characterisation of crop productivity and input needs for agrometeorological advisory services. Journal of. Agrometeorology. 6 (11): 98-105.

World Bank (2006b), "Investments in Agricultural Extension and Information Services", Module 3 in the Investment Sourcebook, World Bank, Washington, DC, $\quad$ http://web.worldbank.org/ WBSITE/EXTERNAL/TOPICS/EXTA RD/EXTAGISOU/0, content MDK: 20930620 menuPK: 2756949 pagePK: 64168445 piPK: 64168309 theSite PK: 2502781, 00.html

\section{How to cite this article:}

Manjusha, K., P. Nitin, D. Suvarna and Vinaykumar, H. M. 2019. Exposure, Perception and Advantages about Weather based Agro-advisory Services by Selected Farmers of Anand District, India. Int.J.Curr.Microbiol.App.Sci. 8(05): 1934-1944. doi: https://doi.org/10.20546/ijcmas.2019.805.224 